\title{
Religious Belief and Scientific Belief
}

\section{Muhsin Mahdi}

\author{
"Are those who know and those who \\ do not know equal!?" (Qur'an 39:9)
}

What we tend nowadays to call "science" in the narrow or strict sense covers the latest developments and discoveries in the mathematical, physical, and biological sciences. Yet the expression continues to be used in a wider sense, one that covers our contemporary social sciences and occasionally human sciences (including perhaps the science of religion) as well. If, when speaking of the Islamic perspective on, or conception of, religious belief, scientific belief, and the relation between them, we mean to address the entire Islamic tradition, we will invariably be faced with an impossible task. To do this successfully, we would have to start from the Qur'an and go through Islamic history century by century, if not generation by generation, and see how the Qur'anic perspective was realized by the Muslim community in diverse regions and disciplines. This process would reveal what tensions and conflicts arose, how these were resolved, and what happened when the Muslim world was faced with the adoption of what we now call "science."

Putting this task aside, we can perhaps touch on a few points in that long and complex history. First of all, we will speak briefly of the Qur'anic perspective and then say a few words about how the different sciences, when developed, were organized into a general scheme of human knowledge and how this organization implies a certain view of the relation between religious belief and scientific belief. This talk will conclude with the raising of some questions regarding what we understand by the term "Islamic science" when we use it as a historical or classificatory notion.

\section{The Qur'anic Perspective}

The Arabic expressions in the Qur'an that are used to signify mental discipline and usually translated into English as "science" are primarily two: "ilm, normally rendered as "science" or "knowledge" (a faculty of sciences is regularly called kullīyat al "ulüm in Arabic, "ulüm being the plural of 'ilm) and hikmah, normally rendered as "wisdom." To begin 
with science or knowledge ${ }^{1}$ one cannot but be struck by the frequency with which words derived from the root ' $-l-m$, from which 'ilm is derived, in the Qur'an. They appear with such persistence that one is forced to reach the conclusion that this is one of the key notions in the Qur'an and therefore of Islam itself. A Muslim hearing or reading the Qur'an can have little doubt that its constant repetition is meant to impress on him/her that this is a matter of great import for one's salvation. There can remain no doubt in the mind of a non-Muslim reading the Qur'an and observing the emphasis placed on this expression that science or knowledge is meant to occupy a central place in Islam.

The presence and importance in a revealed book, which itself holds a central position in the religion, of an expression that is normally perceived as related to secular matters appears as something unnatural to a student of the history of religion. It seems rather unexpected and remarkable, something in need of an explanation, especially since this kind of stress on science or knowledge is not found in the Bible. One is tempted to look for an explanation in the immediate environment, in the cradle of Islam, the heart of the Arabian peninsula and neighboring regions, where Jewish, Christian, Mandean, and other gnostics can be located.

The correspondence between some of the senses of ilm and the Greek term gnōsis tempts one to think of possible influences that may explain this Qur'anic phenomenon. Such a hypothesis appears useful because of the extremely limited role played by science or knowledge in pagan pre-Islamic Arabia, where one would normally look for the source or inspiration of this unusual Qur'anic emphasis. But since our knowledge of pre-Islamic Arabia, including its relations with neighboring regions, in such matters is far from perfect, such a hypothesis is no more than a wild guess. For, perhaps precisely the absence of any interest in and concern for science or knowledge (or the prevalence of ignorance, in that "age of ignorance" [jāhiliyah])," in the immediate environment in the cradle of Islam was the reason for its emphasis. This would be similar to the case of the Qur'anic emphasis on God's unity, as the prevailing norm was certain types of polytheism, against which Islam rebelled. In any case, the remarkably persistent presence of science or knowledge in the Qur'an is echoed by the Prophet, who called himself the city of knowledge: "I am the city of knowledge (madinat al 'ilm) and "Ali is its gate." ${ }^{2}$

\footnotetext{
'The Arabic expression ma 'rifah, used in post-Qur' anic Arabic to refer to something like understanding, is not found in the Qur'an in this sense.

${ }^{2}$ Franz Rosenthal, Knowledge Triumphant (Leiden: Brill, 1970), quotes Tāshköprüzādeh's Miftāh al Sa'ädah, who, in the introduction to his encyclopedia of the sciences, describes "the city of knowledge" as: "The city of knowledge is located far away and is made difficult of access by [strong] walls. On the way toward it, there are mountains with difficult tracks, hills with desolate thickets, and far-flung oceans with high waves."
} 
The word hikmah, usually rendered as "wisdom," is derived from the root $h-k-m$, which expresses something like practical judgment or practical wisdom, the kind of activity associated with decisions made by a judge or ruler (it is understood that this kind of juridical, administrative, military, or political wisdom requires previous experience and knowledge, as well as the ability to make the right decision in particular cases). Thus, wisdom in the sense of practical judgment, perhaps because it has to do with the most important of human affairs, is said to be more than mere science or knowledge: it serves the purpose of science or knowledge-the making of well-constructed or well-fitted (muhkam) things (the physician, because of his healing art, is thus popularly called hakim), as well as pursuing right human conduct and the right way of life.

Wisdom is distinguished from science or knowledge in another way: as comprehensive knowledge of things human and divine, especially the latter, or knowledge of the most important things, and thus distinguished from specialized knowledge and trivial knowledge. In this respect, the distinction between hikmah and 'ilm, which have been rendered as wisdom and science or knowledge, respectively, is comparable to the distinction between sophia and epistèmē in Greek and between sapientia and scientia in Latin. ${ }^{3}$ It so happens that in the case of Greek literature translated into Arabic, sophia (i.e., the knowledge of things human and divine) was occasionally translated as falsafah (i.e., philosophy). Thus, wisdom and philosophy were in some cases used to mean the same thing: knowledge of the remote causes of things or knowledge of the highest things. When used to mean different things, wisdom reverted to its original sense of practical wisdom or else referred to a particular science or art. Hence the use of the expressions "highest wisdom" and "wisdom of wisdoms" to mean the highest science and science of sciences.

\section{The Relation between Religious Belief and Scientific Belief}

If the Qur'an urges Muslims to know and reflect on things, and the Prophet is the "city of knowledge," one might reach the conclusion that the Muslim community is the custodian of the knowledge located in the bosom of the Prophet, as it were. The Muslim community must direct its effort toward recovering, preserving, and propagating this knowledge. To do this, it has to base itself on the Qur'an and the sayings and deeds of

${ }^{3}$ Compare Rosenthal, Knowledge Triumphant, p. 36, quoting G. Furlani, who, in turn quotes Michael the Interpreter, according to whom Syrian Christian philosophers defined knowledge as "the exact understanding of things through cognitive discernment," whereas wisdom "was the good administration of knowledge." Consequently, they said, "every wisdom is at the same time knowledge, but not every knowledge is at the same time wisdom." 
the Prophet, for otherwise it is largely on its own when discovering the meaning, implication, and application, of these sources of knowledge. It so happens that the same sources also urged Muslims to look at and reflect on all things, human and divine, and to seek knowledge wherever it was to be found, even if it were as far away as China, as one of the sayings of the Prophet is reported to have urged Muslims. Then, with the development of all kinds of sciences-those developed out of the early Muslims' own cultural environment such as the sciences of the Arabic language, those developed on the basis of the Qur'an and the sayings and deeds of the Prophet, and those imported from the Greeks, the Indians, and others - the Muslim community itself developed into a vast city of knowledge that required an organized way of communication and traffic lights or policemen to direct traffic.

As thinkers reflected on the multiplicity of the sciences and the relations among them, they developed the basic grouping or division of the sciences into "traditional" and "rational." This division was based on the insight that there are certain disciplines confined principally to particular linguistic, political, or religious communities, and others not so confined. To start with the sciences of language, such as Arabic, these sciences are connected to a particular language, the habits of its speakers, its vocabulary, morphology and syntax, and rhetorical and poetic traditions. The disciplines treating such matters of the Arabic language are different from similar disciplines treating similar subject matters in the Chinese language, for example. The same is true, it was decided, of all particular disciplines that have to do with a particular religion, such as Islam: Islamic theology, jurisprudence, and, in a sense, even mysticism, treat subject matters pertaining to the Muslim religious community, and thus differ from similar disciplines pertaining, for example, to Buddhist or Hindu religious communities. Such disciplines were called traditional, because they deal with subject matters pertaining to the traditions of their respective communities, linguistic or religious as the case may be. While it is true that such disciplines as grammar, theology, or jurisprudence, as practiced within different linguistic or religious communities, may use similar or common methods when dealing with their respective subject matters, and that there may be influences and interactions among them, none of this transforms these disciplines into grammar as such, theology as such, or jurisprudence as such-they remain the grammar of this or that language, the theology of this or that religion, and the jurisprudence of this or that legal system. Of course one may invent a discipline called grammar as such, or theology as such, or jurisprudence as such, but the product, if genuine, is certainly something quite different from the disciplines about which we have been talking.

Contrasted to these traditional sciences-some of these disciplines were also called homespun, legal, or religious sciences, depending on the 
discipline in question-are the rational sciences. This does not mean that the traditional disciplines are irrational or nonrational, for in some cases they display more rational ingenuity and even extreme rationalism when compared to the so-called rational disciplines. Nor does it mean that the subject matter of the traditional disciplines is necessarily irrational or nonrational, even though in some cases it is hard to provide a rational account of the subject matter of a particular language or theological discipline. In some cases, the subject matter is presented explicitly as transcending human reason. Rather, it means that the rational disciplines treat or can treat the same subject matter whenever and wherever it is pursued, regardless of the language, religion, and legal system of the community pursuing it. This is why they are also called the philosophic, ancient, and foreign sciences. These names do not indicate their origin in earlier times and in foreign lands-but that they can move freely across linguistic, national, and religious borders, and point to their universal human character. Here again, one should not misunderstand these descriptions. To call a discipline rational or universal does not mean that its theoretical principles, methods, or practical consequences are above suspicion, or that it cannot be refuted or changed, improved or transformed. What it means is that for one to engage in a discussion of its principles, methods, or conclusions, one must use one's God-given reason, which anyone can do regardless of linguistic, national, or religious affiliation.

Due to these reasons, when we ask about religious belief and scientific belief and the relation between them as a question within the Islamic tradition, we may have to formulate the question as follows: If religious belief is based on the Qur'an and the Prophet's sayings and deeds, explicated and developed by such religious disciplines as Islamic theology and jurisprudence, what is the status of the rational disciplines, which in the Islamic tradition included or could include everything we now call "science" in the narrow or strict sense? Is a believing Muslim under a religious obligation to study them? Is he/she forbidden to do so or free to choose? In the area of choice, is he/she encouraged or discouraged from pursuing them? This is the way Ibn Rushd, a distinguished Muslim theologian, jurist, and philosopher, posed the question. His answer, which is supported by the historical pursuit of these disciplines in the Muslim community, is that a believing Muslim is urged to pursue them and accept their conclusions, as long as they have been reached in the proper manner (whether one can call these conclusions scientific belief and set them up as paralleling religious belief is another matter). Indeed, a Muslim is under a religious obligation to do so if he/she has the requisite qualifications, which include moral probity and intellectual honesty.

It would be foolish to claim that the Muslim community reached full consensus on this issue. One tenth-century theologian, when asked what he would do if he met a philosopher in paradise (presumably a full- 
fledged Muslim philosopher whom God had granted paradise), said that he would break his neck with his own hands. ${ }^{4}$ Many practical questions were raised regarding the practice of these disciplines and its impact on the practitioner and the community at large. For example, al Ghazāli warned those who study and admire the accuracy or correctness of the conclusions of mathematics and physics not to be fooled into believing in the accuracy of the conclusions of metaphysics. He cautioned against letting these affect their religious belief about creation, the soul's immortality, and the hereafter's rewards and punishments. Other Muslim theologians and jurists avoided these disciplines and thought they led, or could lead, to religious unbelief or the weakening of one's firm attachment to what they believed were the correct religious beliefs. A universal religion tends to produce all kinds of theological schools that reach different conclusions, even on such an important issue as this one. The Prophet predicted this state of affairs and declared: "Differences of opinions among the people of my religious community is a sign of divine mercy."

\section{What Is Islamic Science?}

This is how things stood until recently. In recent decades, the climate of opinion changed and a new tradition in the study of the history of the sciences in the Muslim world was formed in both the West and the Muslim world. I shall begin with some of the conceptions underlying the general histories of Islamic science produced in the West, both because they are interesting and because they influence the way Muslims, or at least some Muslim intellectuals, are beginning to conceive the problem.

General histories of Islamic philosophy and science (here, again, philosophy and science cannot be separated easily) usually begin with the legacy of the ancient world, especially the Greek and Greco-Roman worlds, and speak occasionally of possible ancient Iranian and Indian influences. Then they turn to the Hellenistic Middle East of the seventh century and the translations and translators from Greek into Syriac, Syriac into Arabic, and Greek into Arabic. Along with this, they treat the survival of the Neoplatonic school or schools that tended to harmonize, but often to confuse and be confused about, the views of various authors and schools. Finally, they make a show of historical ingenuity by setting the record straight about the differences among these authors and schools. ${ }^{5}$

\footnotetext{
${ }^{4}$ See Ibn Battā, Kitāb al Sharh wa al Ibānah 'alā Usūl al Sunna wa al Diyānah (Cairo: 1984).

SThe question of the transmission of Greek science through the Arabs to the West has a long history that need not concern us here, except perhaps to note the rise and decline of the idea of "influence" in this history, how the estimates of the significance of the Arabic tradition have waxed and waned during the past century, and how the more recent
} 
As one looks at these histories of Islamic philosophy and science and asks oneself "What is Islamic science?" and "What is meant by its history?", one's first impression is that Islamic science is some sort of harmonization between something called "science" and another thing called "religion" and, in particular, that it is some sort of harmonization between what was essentially Greek and Hellenistic science (as distinguished perhaps from Indian or Chinese science) and Islam (as distinguished perhaps from Christianity or Buddhism). Then one begins to wonder on what basis can science in general be divided into different kinds of science: Greek science, Indian science, Christian science, and so on. Are these simply convenient ways of identifying a group of thinkers who belong to a particular cultural or linguistic or national tradition? Or does the division indicate more fundamental differences-such as different outlooks on the nature of the scientific enterprise, its principles, or methods-to the point that the expression "science" must in fact mean something like a particular human attitude or human stand?

Whatever one's inclination may dictate in answer to these questions, one must also consider the situation that prevailed in the study of philosophy and science until relatively recent times, especially among those thinkers who are acknowledged to have been philosophers and scientists themselves, who presumably knew what they were talking about when they spoke of philosophy and science, and who were not unaware of the fact that philosophy and science had been pursued by persons of different cultural, linguistic, or national traditions. Were one to address these questions to Euclid, al Bīrūnī, Ibn Rushd, or Aquinas, they would surely have answered that such a division of philosophy and science is at best accidental; it does not touch the substance of philosophy and science, even though it may have something to do with the way they are expressed. It is perhaps something like the division of the human race into black and white. Just as this division does not touch the nature or essential unity of the human race, the corresponding division of philosophy and science into different cultural, linguistic, or national traditions does not touch its essential unity. This does not mean that these philosophers and scientists were not aware of, let us say, the different philosophers' and scientists' backgrounds, personal experiences, languages, and national or cultural traditions. They were. But they saw no contradiction between admitting the existence, and in some respects even the importance, of these things and giving philosophic and scientific activity a

realization that many of Aristotle's writings were translated directly from Greek into Latin, rather than through Arabic as an intermediary. This last factor does not settle the broader questions of what created the demand for these texts and how they were interpreted once the demand was met, both of which take one back to the new learning made available through Arabic science and to the role of Avicennan Augustinism and Latin Averroism (Avicenna is the Latinized name of Ibn Sīnä'). 
somewhat independent field of operation. To understand the Islamic tradition on the relation between religion and science, one must learn to appreciate this view and this way of looking at philosophy and science.

Does the same situation obtain in the case of religion? Linguistic usage indicates already that we see the situation here to be somewhat different than in the case of philosophy and science. We have substantives that designate each member of this group we designate as "religion" - we say Buddhism, Islam, Christianity, and so on-and we use these substantives in preference to such expressions as "Islamic religion" or "Christian religion." We do not really think that "religion" as a species, as it were, possesses an essential unity. Rather, we tend to think that the essence of religion resides not in the species but in each of its individual members, even though they all have certain common characteristics or properties. So, compared to the relation between philosophy and science, on the one hand, and whatever we mean by the different philosophic or scientific traditions, on the other, the relation between religion in general and individual religions seems to be quite different. I must add that this is not primarily the philosophic or scientific understanding of the situation; it is, to begin with, the way pious members of any religious community understand the relation between their religion and other religions.

Let us now turn to "Islamic science." If one stresses "Islamic," one will be thinking of Islamic science as distinguished from other aspects of Islam or other things that either constitute Islam-that is, whose essential character is defined by their relation to Islam as a religion-such as Islamic law or Islamic theology, which can be called Islamic in a strong sense. If, on the other hand, the stress is on "science," then Islamic science is being distinguished from, let us say, Greek science or Buddhist science. Within this wider group called "science," one is also apt to think that "Islamic science" belongs more properly to a particular group that begins with the adjectival form of a particular religion, to the group that includes "Jewish" science, "Christian" science, "Buddhist" science, and so on (but not Greek science or German science, which belong to another group whose members are identified as pertaining to particular nations or languages). Thus, the name that designates that group will have to be something like "religious science" - an expression that should tell us immediately that we are about to end with an absurdity of some sort.

What, exactly, does "religious science" mean? Does it designate a relationship (harmonization and so forth) between science in general and religion in general? Or, if there is no such thing as religion in general, does it perhaps designate the relation between science in general and each one of a number of religions? One must admit that the latter designation is more likely to be the case, since students of comparative religion or the history of religions who attempt a global understanding of religion from a religious point of view either begin or end, and usually begin and end, 
by understanding all religions from the view of their own religion. ${ }^{6}$ From the view of religion itself, then, science in this sense-that is, apart from what we called the religious sciences earlier-cannot be prefixed with "religious" in any strong sense, for it does not admit of being particularized in the same way as religion. We can of course study how each particular religion works out its relation to science, or harmonizes itself with science and, conversely, how science works out its relation to each particular religion. It may also happen that certain religions (i.e., Judaism, Christianity, and Islam) share some common traditions or characteristics and that science can relate itself to them in ways that may look similar. But this will not change the situation in a radical way.

To help us overcome our resistance to this view, remember how things stood until relatively recent times. When we call philosophy or science Islamic, Jewish, or Christian, we mean the scientific thought of such leading figures as Ibn Rushd, Maimonides, or Aquinas. Yet none of them used this expression in the sense in which we mean it today. They had no difficulty in understanding, appreciating, or even approving of a situation in which a particular religion, especially their own, had to take a stand on science, harmonize its beliefs with scientific views, or defend these beliefs against scientific criticism. They understood and appreciated situations in which science had to accommodate itself to a prevailing religious doctrine. But this is quite different from what we wish to mean by such an expression as "Islamic science." As we mean it today, this phrase would have sounded strange, if not meaningless, to these thinkers. Since our first task is to understand their view (for we are being called upon to understand the attitude of a religious tradition to science), we must try to understand why they found the notion behind our understanding of this expression objectionable, to say the least.

This notion is one of the by-products of a relatively recent theological current in the dominant traditional wing of the currently dominant religion in the West: Catholicism. It is the stepchild of the notion of "religious philosophy" as developed in those Catholic intellectual circles that sought to renew the theological and philosophic thought of Thomas Aquinas. According to these interpreters of Aquinas, his theological and philosophic thought together constitute what they call a "Christian philosophy." One author who defended this view and incorporated the expression "Christian philosophy" in his writings was Étienne Gilson, whose monumental erudition and popular books, such as History of Christian Philosophy in the Middle Ages, had an impact on the contemporary

${ }^{6}$ At least this is what one of my teachers, Joachim Wach, used to say, even though these may not have been his exact words. See the conclusion of his essay, "The Place of the History of Religion in the Study of Theology," in his Types of Religious Experience: Christian and Non-Christian (Chicago: University of Chicago Press, 1951). 
literature of other religious traditions, especially Jewish and Islamic, where authors try to develop parallel points of view and establish a relation between each of these non-Christian religions, and philosophy and science, that is more or less identical with the relation between Christianity and philosophy as understood by Gilson.

One must remember, however, that Gilson's "religious philosophy" was grounded in a situation somewhat unique to Catholicism. To begin with, one has to think of the central position of theology in Christianity, at least in the Catholicism of the Middle Ages, the theology that is said to have been the queen of the sciences. There is also another element, again something unique to the Catholicism of the Middle Ages: a certain view of the supernatural in a rather technical sense and its relation to the natural order, especially to natural or unaided knowledge. Nothing similar is present in any other religion, certainly not in the precise sense given to it by Aquinas, who apparently was the first to formulate it. The role played by Greek philosophy in the formation of Christian theology, both in the Patristic Age and in the Middle Ages, and the philosophic origin of the notion of the supernatural in the Neoplatonic philosophic tradition, are important questions that must also be kept in mind. However, the central position of theology and the distinction between the supernatural order and the natural order set Catholic thought in the Middle Ages and its renewal in modern times apart from almost every other religion.

This leads to the following difficulty: In Christianity, at least according to the Neothomist view, the question of the relation between theology and philosophy and science, and the parallel question of the relation between the supernatural order and the natural order, have already been worked out in a way that places them in a definite hierarchy. This makes the notion of a "religious philosophy" or "religious science" intelligible and meaningful. But does this notion make sense in other religions, where the status of theology remains quite subordinate and the distinction between the supernatural order and the natural order is not formulated in this fashion or is even absent in the strict sense in which it was understood by Aquinas? And given that this is the situation, can one go on to assume that this kind of harmonization or synthesis between religion, and philosophy and science, existed in these other religions?

One cannot answer these questions by trying to find in other religions the closest approximation to the Medieval Catholic position, as understood or interpreted by Aquinas, or by assuming that other so-called medieval religions must have the essential ingredients of medieval Catholicism. One must look at each religion from the inside (according to its own genius, as it were), determine the position of theology, and philosophy and science, within the religion in question, and then determine in what sense one can still speak, if at all, of a religious philosophy or 
science. One may have to reformulate the question of the relation between religion and science, and one may find that one needs as many formulations as there are religions. There is no other way to decide the question. Transferring the notion of religious philosophy, as developed by such authors as Gilson, to other religions must be abandoned.

As the position of theology in Islam is quite different from its position in Christianity, many students of Islam - non-Muslim and Muslimhave been looking eagerly for a substitute for theology. All right, they say, theology is not the queen of sciences in Islam. Which discipline, then, is the queen of the sciences? They have already decided that the sciences are like ants or bees who must have their queen, their regime must be monarchic, and the monarch must be a fair lady. Assuming all this and that the fair lady must be a so-called science, some elect and enthrone mysticism, jurisprudence, the principles of jurisprudence, and then try to rearrange the ranks of the other sciences in order to set up what they know already to be the proper relationship between religion and science in Islam. Apart from the fact that mysticism, jurisprudence, and the principles of jurisprudence do not enjoy the same status in Islam as did theology in Christianity, the difficulty is that none of them can deal with science in the same way that theology was able to deal with it in medieval Catholicism. After all, theology began and developed as an attempt to combine philosophy and Christian religious doctrines. It was able to look at the entire range of religious and human experience, including philosophy and science. I do not think one can say the same thing about mysticism or jurisprudence in Islam. One may even say that they are constitutionally unable to perform such a task.

If one assumes that the notion of a religious philosophy or religious science is viable, such are the questions that must be looked into before its application to different religions can be justified and before one can speak of such things as Christian, Jewish, or Islamic science. But I do not believe that one can leave it at this, for there is a powerful strain in modem philosophy that asserts that the very idea is absurd, a round square, a misunderstanding. It cannot exist. ${ }^{7}$ It must be understood, of course, that one does not mean that there were no philosophers and scientists among Christians or members of other religious communities, or that there were no genuine philosophic and scientific inquiries conducted by persons who professed a particular religion. The argument is directed against the enterprise as such, against the idea of a religious philosophy or science as presented by the Neothomists, an idea which, as we saw, was extended or applied to other religions.

${ }^{7}$ This position has been presented openly and forcefully by Martin Heidegger. One also finds it stated in a course of lectures he gave in 1935, translated by Ralph Mannheim into English under the title An Introduction to Metaphysics (New York: 1961). 
Now, why is it absurd? Why is it a round square? Because science and religion in general are seen as radically different things, if not as irreconcilable enemies. The very idea of science, the essence of science, is that it is the unaided effort to understand everything, including religion and God, by questioning everything and by pushing this questioning to the very end. The idea of religion, on the other hand, is faith, belief, and submission. From its standpoint, philosophy is foolishness. The proper function of each is to pursue its own end, and these two ends are radically different. Neither philosophy nor religion (and theology) should confuse things and muddy the waters in the pursuit of an impossible task.

Nevertheless, it is possible to harmonize science and religion. Harmonization begins with what is possible. One can begin with the notion that there is a hierarchic scheme within which science can take its place but in which theology rules. This is one way to proceed. But one can also begin with the view that religion and science are totally and radically different things and then say that this is precisely the reason why they need to be harmonized, why one should try and bring them together as far as possible rather than sharpen the conflict. Because science and religion are in eternal conflict, a conflict that can make human life impossible and in most situations make the pursuit of science impossible, the only way to preserve them both is to blunt their sharp edges and enable them to live together. This is also a kind of harmonization.

There is more than one way, then, in which science and religion can be harmonized. The two may be presented as having a harmonious relationship with no inner tensions at all. In this case, the task consists of making explicit their preexisting harmony. Or one may present them as two radically different things that need to be harmonized nevertheless. True, one is dealing with a square and a circle. But, for certain reasons, which may happen to be necessary from the point of view of both religion and science, the conflict between them should not be allowed to become too bloody, and the two should and could learn to tolerate each other and live alongside one another. It is perhaps even possible for them to live alongside one another, with religion presenting and defending its own claim that everything is to be seen from its own point of view of faith or submission, and also science presenting and defending its own claim that human beings, or at least a few human beings, can and should make the effort to understand everything, including religion, from the point of view of unaided human reason or whatever other powers human beings are endowed with by nature or can acquire by their own effort.

These two possible points of view or ways of harmonizing science and religion coexisted in the Islamic tradition. I believe that it is useful to keep the resulting approaches distinct rather than confuse the one with the other. But there are certain thinkers, who are called Muslim scientists and who begin with faith or submission or the generally accepted beliefs 
of the Muslim community, and then try to harmonize science with this position. A good example is al Ghazāli, who surveys the religious and nonreligious sciences in his so-called autobiography The Deliverer from Error. He says something to this effect: philosophy in general may be alright, but the situation differs from one scientific discipline to another. Logic is fine and can be used as a tool of reasoning. There is nothing wrong with natural science and mathematics either, provided one accepts the notion that God is the maker of everything and the cause of the harmony present in nature. Metaphysics presents a number of problems, and so he lists the particular questions where the conclusions of metaphysics do not agree with religious beliefs and then argues against and ultimately rejects them. As for ethics and politics, finally, most of the ideas contained in these disciplines were originally given by the prophets and are therefore acceptable. He finds a way to integrate philosophy and the sciences included under philosophy into religion from a point of view that is neither philosophic nor scientific. There are many others, especially among the later philosopher-theologians, who try to integrate science and religious doctrine in this manner. In every case, what must be watched for is not what the thinker engaged in this enterprise says here or there, but his haltung, the position upon which he takes his stand.

There is a second tradition, which begins with science or takes its stand here and tries to harmonize religion with it as far as possible without abandoning science. Here, religion becomes a subject of study, even the subject of a particular science. For instance, in al Fārābī's Enumeration of the Sciences, the sciences are divided into the study of the language, logic, mathematics, physics and metaphysics, and something called political science or political philosophy, which includes the study of divine laws: jurisprudence (the science of the divine law's application) and theology (the science of the divine law's defense). Religion finds its place within a philosophic science, and these two religious sciences find their place within a global scientific view. Religion and the religious sciences are understood and judged on the basis of a philosophic or scientific explanation of revelation and prophecy and of the function of the religious sciences, including theology, within the religious community.

Ibn Rushd adopts substantially the same position. He asks al Ghazāli what, according to him, are the basic points of conflict between philosophy or science and religion. Then he says that we must look at the Qur'an and the divine law and what the theologians say, and see whether you, al Ghazälī, have the right to say that Islam contradicts philosophy or science on this or that question. We must go back to the Qur'an and the divine law. We must go back to the sources. And then we must look at your interpretation of the sources. By what right do you interpret the sources in this manner? It is true that you are a jurist, but I, Ibn Rushd, 
am also a jurist. I happen to be both a philosopher and a practicing judge. I have looked into the case of religion versus philosophy, studied the briefs of the parties, and find that the whole case is based on a misunderstanding. Legally speaking, it is my considered opinion that there is not a case here. I have therefore decided to throw the case out of court, declaring, in addition, that you have harmed religion as well as science by muddying the waters.

It is not that Ibn Rushd is unconcerned with religion or that he has abandoned religion; he has found out that this particular religion, Islam, demands the study of philosophy and the sciences, demands that they be pursued by those who are able and have the qualifications to pursue them wholeheartedly and without reservation. It is true that the religion also demands the preservation and protection of the religious beliefs of the vast majority of Muslims who are not philosophers or scientists, and that philosophy and science will have to submit to the demand of religion in this respect. But this does not touch the core of philosophy or science. Both traditions, represented by al Ghazālī and Ibn Rushd respectively, may be called Islamic, for they are concerned with the problem of the relation between science and the authoritative sources of the religion. They see the relation between science and Islam differently, but they are not willing to abandon either Islam or science.

As one proceeds with the study of Islamic philosophy and science, however, one will find, on the margin, two further traditions that are more radical. There were those (and for obvious and compelling reasons they were not numerous) who did not care for religion at all. They said openly that religion is a lie and a deceit and that a person can live quite well, indeed one is better off without it. The thinker who became notorious for holding this position is the famous physician al Rāzī. But there were others before him-al Sarakhsī, a student of al Kindī, is said to have been another. There were others who took this position, but most of them were not philosophers or scientists, but what we might call radical intellectuals. It is quite characteristic of philosophy in the Islamic community that it recoiled from this position. In fact, such philosophers as al Fārābī wrote refutations of the position of al Rāzi and his friends. This is the radical left, as it were.

Then there is the opposite tradition (one can assume that it was adhered to by the majority of Muslims, and if the truth of religion were to be decided by a majority vote, they would decide the case), which did not care for philosophy or science, except perhaps for such indispensable practical sciences as medicine and building bridges. This is quite natural. The community of the faithful who did not care for philosophy or science are like today's solid citizens who do not care for atomic physics. We do not blame them for it, for it is not their business. But those people had leaders and representatives who tried to defend their position in the name 
of the community as a whole, before philosophy and science, and against philosophy and science. It is interesting to study the arguments and positions of these radical traditions, because they tend to throw light on the arguments and positions of those who decided to follow the middle way.

Turning to the Islamic world of today and the way it tends to conceive the relation between religious belief and scientific belief, we must begin with the use of the history of "Islamic science" in contemporary Arab and Muslim ideology. This is based on the following proposition: Western science is Arab science or Muslim science developed further. Hence it can be freely taken back without the expectation of serious difficulties. Or else one suggests that the Arab world is part of the West, ${ }^{8}$ and therefore there can be no difficulty in adopting modern science.

In contrast to this liberal ideology, one observes the more recent development of multiple allegiances: to the West as a necessary evil, but more naturally and traditionally to Africa, Asia, and the Third World, which means that the Islamic world becomes more conscious of such questions as backwardness and dependence in relation to the West. This has led to the raising of serious questions regarding the role of modern science in Muslim societies. There is the question of the role of science in political culture, such as the way modern science and technology become instruments of tyranny rather than the rule of law. There is the manner in which science and technology promote technocracy, create an elite and specialized technical schools dedicated to practically oriented research and problem-solving and end up becoming isolated from the general educational system, which is then neglected and becomes impoverished. There is the role of modern science in the social revolutions and the multiple upheavals-economic, political, intellectual-that Muslim societies have been undergoing in a relatively short period. And there is the whole difficult question of the role of science and technology in propaganda and public relations, or how science creates the appearance of knowledge.

These are all interesting and difficult questions that obviously have much to do with the way a society conceives the relation between religious belief and scientific belief. However, at the present time we cannot go into any detail, because they do not belong to the Islamic tradition.

${ }^{8}$ Consider, for example, Taha Hussein, The Future of Culture in Egypt, translated by Sidney Glazer (Washington, DC: 1954). 